\title{
Seventy years of the Chagas disease Bambuí Project: celebration and perspectives
}

\author{
João Carlos Pinto Dias ${ }^{[1]}$ and Christiane Santos Matos ${ }^{[1]}$
}

[1]. Centro de Pesquisas René Rachou, Fundação Oswaldo Cruz, Belo Horizonte, MG.

In December 1943, Dr. Emmanuel Dias initiated an ambitious scientific project in Bambuí (State of Minas Gerais, Brazil) to address the epidemiology and control of Chagas disease ${ }^{1-3}$. Three years prior, Amilcar Martins and collaborators had described a hyperendemic incidence of the disease in that region based on the detection of 25 acute cases and a high level of housing infestation by Triatominae bugs ${ }^{1,4,5}$. At that time, the recognition of this disease was very difficult and mainly limited to acute cases discovered by Carlos Chagas himself and Argentinian and Uruguayan researchers, namely, Romaña, Mazza and Talice ${ }^{3,5}$. Invited by Martins, Dias and Romaña immediately visited Bambuí and produced a historical report with a prophetical prognosis that a local center for the study of Chagas disease would provide a tremendous improvement in the knowledge and control of this trypanosomiasis ${ }^{3,6,7}$. In the face of difficult circumstances, Dias was charged by his director, Dr. Henrique Aragão, to proceed with this task ${ }^{1,3}$. In addition to the description of other acute cases of Chagas disease, Dias's attention soon was drawn to the innumerable chronic cases, most of which presented with severe cardiopathy, which was responsible for premature deaths throughout the region. Within a few months, Dias wrote that it was urgently necessary to stop the transmission of Chagas by means of a drastic reduction in the number of domiciled vectors, an ambitious effort implemented via housing improvement, intensive health education and the use of available insecticides and physical tools such as flamethrowers, kerosene, caustic soda and hydrocyanic $\operatorname{gas}^{1-3,7,8}$. In parallel, the chronic disease also needed to be addressed. This task required improved diagnostic and clinical characterization, especially for cases involving heart disease ${ }^{1,5,9,10}$. Enthusiastic and ever determined, Dias recruited several colleagues from the Oswaldo Cruz Institute into various aspects of the project. These colleagues included an immunologist (Julio Muniz), pathologists (Aloisio Miranda and Magarinos Torres), an entomologist (Herman Lent), general physicians (Genard Nóbrega) and a cardiologist (Francisco Laranja). Additionally, José Pellegrino of Belo Horizonte was charged with assisting in insecticide trials

\footnotetext{
Address to: Dr. João Carlos Pinto Dias. CPqRR/FIOCRUZ. Av. Augusto de Lima 1715, Barro Preto, 30190-002 Belo Horizonte, MG, Brasil.

Phone: 5531 3349-7763

e-mail: jcpdias@cpqrr.fiocruz.br

Received 3 September 2013

Accepted 25 September 2013
}

and experimental cardiopathy ${ }^{1-3}$. As an immediate result, various aspects of the transmission and morbidity of Chagas disease were elucidated by means of well-planned epidemiological investigations, which were performed among non-selected regional populations and included serology coupled with entomology, electrocardiography and clinical data. Within a few years, the group had obtained an efficient insecticide (Gammexane) and elucidated the systematization of the basic clinical, epidemiologic and pathologic aspects of chronic cardiopathy due to Chagas disease $e^{1-3,5,9-11}$. At the beginning, the Center was installed in a modest house rented by the Institute. In 1951, a new and modern building was constructed using state, federal and municipal resources ${ }^{1}$ (Figure 1).

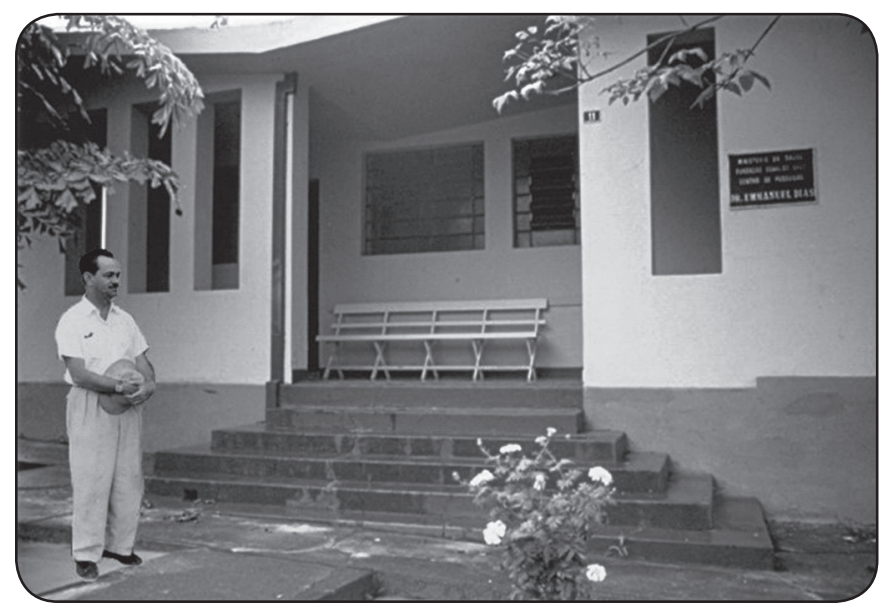

FIGURE 1 - The Emmanuel Dias Research Center in Bambuí, State of Minas Gerais, Brazil (PAEED - Posto Avançado de Pesquisas Emmanuel Dias), and its founder, Dr. Emmanuel Dias (27/07/1908-22/10/1962). Photo by João Carlos Pinto Dias: 1951.

The control activities in Bambuí had an extraordinary impact, swiftly diminishing the incidence of acute cases and, consequently, the prevalence of infection in young individuals ${ }^{1-3,7,10,11}$. Convinced of an urgent need to expand the fight against triatomine bugs, Dias initiated a fact-finding tour throughout Latin America and international agencies in the middle of the 1950s, insisting that vector control was a feasible and undeferrable task ${ }^{2,3,7}$. At the same time, the incidence and 
severity of the disease began to be recognized in several endemic areas where the epidemiological model tested in Bambuí was implemented. By involving governors and health authorities, chiefly Mario Pinotti, the leader of Brazilian Malariology and his friend, Dias achieved the implementation of vector control throughout a large area of the States Minas Gerais and São Paulo. This trial was so successful that the results stimulated the creation of the National Programme for Chagas Disease Control $1^{1-3,5,7,8}$. Emmanuel Dias died prematurely in 1962, although the work in Bambuí was continued by the staff of the Institute Oswaldo Cruz and, subsequently, by the René Rachou Center, headquartered in Belo Horizonte. In 1979, the center was rechristened Posto Avançado de Pesquisas Emmanuel Dias (PAEED) by the president of the Oswaldo Cruz Foundation (FIOCRUZ), Dr. Guillardo Martins Alves ${ }^{2,10}$. The legacy from the pioneering first 20 years provided three basic directions: to maintain and improve vector control, to describe the natural history of human Chagas disease (HCD) via the systematic and longitudinal follow-up of infected individuals and to seek new options and tools for the medical management of chronic patients. With such a perspective, a new phase of vector control was implemented in the municipality in 1974, consisting of an epidemiological surveillance of triatomines carried out at the municipal level and supported by extensive community participation. In parallel, new insecticides were tested as replacements to the proscribed Gammexane; members of the pyrethroid group were mainly used because they have greater residual action and are less harmful to humans and the environment ${ }^{2,7,11}$.

The dynamics of the natural foci of Panstronylus megistus, the principal species that continued to invade artificial ecotopes, was thoroughly studied in the area, as was the role of sylvatic reservoirs of this parasite, mainly synanthropic marsupials. The follow-up of hundreds of patients, involving decades of evolution, revealed the progressive character of the infection and the various risk factors related to the development of the disease. In parallel, several important issues, including social aspects, diagnosis (new serologic techniques, polymerase chain reaction (PCR) and hemocultures), heart disease management, follow-up of mortality, management of digestive forms, the occurrence of co-morbidities and the specific aspects of the disease in geriatric groups, have been studied by PAEED in recent decades ${ }^{12}$.

Today, as a product of continuous entomological surveillance and a decrease in the magnitude of outbreaks of sylvatic P. megistus resulting from intense anthropic action combined with an expansive rural exodus and the improvement of dwellings, the transmission of HCD is virtually suspended in Bambuí. A recent investigation among a non-selected population (1,782 individuals) showed that infected individuals beyond the fourth decade of life could no longer be identified (a unique exception being a 34-year-old woman who never lived in rural areas and whose mother is seropositive). A general disease prevalence of $7.74 \%$ is restricted to individuals greater than 50 years old, with a median age of 66 years and with no differences due to gender, in contrast with the levels of approximately $60 \%$ found in the 1950s involving all age groups ${ }^{10-12}$. Independent of age, approximately $17.6 \%$ of the seropositive group has the indeterminate clinical form of HCD. Chagas heart disease and chronic digestive disturbances due to infection were found respectively in $70.6 \%$ and $53.9 \%$ of the patients The association of heart and digestive disturbances (cardiodigestive form) represented $40.1 \%$.

The concomitance of HCD with other chronic and degenerative diseases increases with increasing age of the patients. Genotypes TcI and TcII of the parasite are still circulating in Bambuí among vectors, reservoirs and humans. Of 58 patient hemocultures performed, $45(77.6 \%)$ tested positive for the TcII genotype, with two cases of mixed infection by TcI and TcII ${ }^{12,13}$.

In such a landscape, studies of HCD in Bambuí are coming to a natural end. This historical endeavor has resulted in the publication of more than 400 scientific papers and dozens of theses over the last 70 years and has provided the continuous training of professionals and an immeasurable service to the community, the country and science. In conclusion, the entire history of this small center should be celebrated as a dream of pioneers and the realization of a beautiful struggle against an important and often neglected illness. The center's mission was fulfilled with extraordinary success.

The present moment necessitates definition of the future of PAEED. Among several options, given the long history of PAEED and the epidemiological setting of this region, the best thing to do seems to be the transformation of this research center into a Regional Service Center of Reference and Research in Cardiology, with joint leadership by the Oswaldo Cruz Foundation, the City Hall of Bambuí and the Regional Health System of the State of Minas Gerais. After several productive preliminary interactions, State of Minas Gerais and the City of Bambuí have demonstrated enthusiastic support for this proposition, and FIOCRUZ must now assess its own interest and willingness to implement this new mission.

\section{CONFLICT OF INTEREST}

The authors declare that there is no conflict of interest.

\section{REFERENCES}

1. Dias E. O Centro de Estudos e Profilaxia da Moléstia de Chagas em Bambuí, Estado de Minas Gerais. Notícia histórica em homenagem ao Professor Henrique Aragão. Mem Inst Oswaldo Cruz 1956; 54:309-357.

2. Dias JCP. Cinquenta anos de Bambuí. Rev Soc Bras Med Trop 1993; 26 (supl II):4-8.

3. Kropf SP. Doença de Chagas, Doença do Brasil: ciência, saúde e nação, 1909-1962. Rio de Janeiro: Fiocruz Editora; 2009.

4. Martins AV, Versiani OC, Tupinambá AA. Sobre 25 casos agudos de moléstia de Chagas observados em Minas Gerais. Mem Inst Ezequiel Dias 1940; 3-4:1-66.

5. Coura JR. Síntese histórica sobre a evolução dos conhecimentos sobre a doença de Chagas. In: Dias JCP, Coura JR, editors. Clínica e Terapêutica da doença de Chagas. Uma abordagem para o clínico geral. Rio de Janeiro: Fiocruz Editora; 1997; p. 469-486.

6. Dias JCP. A descoberta do foco e a instalação do Posto do IOC em Bambuí. In: Dias JCP, editor. Dr. Emmanuel Dias (1908-1962). Rio de Janeiro: Fiocruz Editora; 2008. p. 142-147. 
7. Dias JCP, Schofield CJ. The evolution of Chagas disease (American Trypanosomiasis) control after 90 years since Carlos Chagas discovery. Mem Inst Oswaldo Cruz 1999; 94:103-122.

8. Dias E. Profilaxia da doença de Chagas. O Hospital 1957; 51:53-68.

9. Laranja FS, Dias E, Nóbrega GC, Miranda A. Chagas' disease. A clinical, epidemiologic and pathologic study. Circulation 1956; 14:1035-1060.

10. Dias JCP. Doença de Chagas em Bambuí, Minas Gerais, Brasil. Estudo clínico-epidemiológico a partir da fase aguda entre 1940 e 1982. [Thesis]. [Belo Horizonte]: Universidade Federal de Minas Gerais; 1982.
11. Laranja FS, Dias E, Duarte E, Pellegrino J. Observações clínicas e epidemiológicas sobre a moléstia de Chagas no Oeste de Minas Gerais. O Hospital 1951; 40: 137-192.

12. Matos CS, Santos JE, Dias JCP. Present situation of human Chagas disease prevalence in Bambuí municipality, Minas Gerais, Brazil. Mem Inst Oswaldo Cruz 2013; In press.

13. Zingales B, Andrade SG, Briones MRS, Campbell DA, Chiari E, Fernandes $\mathrm{O}$, et al. A new consensus for Trypanosoma cruzi intraspecific nomenclature: second revision meeting recommends TcI to TcVI. Mem Inst Oswaldo Cruz 2009; 107:1051-1054. 